\title{
KEMAMPUAN RESOLUSI KONFLIK INTERPESONAL DALAM MENGUATKAN MORAL KOGNITIF SISWA SEKOLAH DASAR
}

\author{
Dianasari $^{1}$, Bunyamin Maftuh ${ }^{2}$, Elly Malihah ${ }^{3}$, Yayuk Hidayah ${ }^{4}$ \\ ${ }^{1}$ Universitas Muhammadiyah Cirebon \\ 2,3 Universitas Pendidikan Indonesia \\ ${ }^{4}$ Universitas Ahmad Dahlan \\ 1dianasari@umc.ac.id
}

\begin{abstract}
Interpersonal conflict resolution education is peace education relevant for Elementary School students. This education answers the disruption that occurs in Indonesia, and influences the pattern of conflict resolution education for elementary school students. The purpose of this study was to see the understanding of interpersonal conflict resolution in students, and to evaluate the form of peace education applied at SDIT Sabilul Huda Cirebon. The research was conducted with a qualitative research approach. Qualitative research in measuring students' interpersonal conflict resolution skills in strengthening students' cognitive morals is a description of students' everyday social world at school. The object of research is the teacher at SDIT Sabilul Huda Cirebon City. The results showed that based on the eight question indicators. Namely the teacher's understanding of conflict resolution education/peace education for elementary school children, the purpose of providing conflict resolution education/peace education for elementary school children, a form of habituation of conflict resolution education/peace education for elementary school children, reasons for implementing conflict resolution education/peace education for elementary school children in, the form of school support provided in conflict resolution education/peace education for elementary school children, the form of awareness and ability of elementary students in resolving interpersonal conflicts, the form of changes in knowledge and attitudes shown by elementary students, and future school programs that will be implemented for improve conflict resolution education I peace education for elementary school children. These eight indicators were developed in the interview instrument for the teacher. It can be concluded that in interpersonal conflict resolution education at SDIT Sabilul Huda, the teacher's understanding of the meaning, goals, reasons, and forms of habituation of conflict resolution/peace education learning is very good. This is due to the support of schools that always provide counseling for teachers.

Keywords: cognitive moral; elementary school; interpersonal conflict resolution
\end{abstract}

\begin{abstract}
Abstrak
Pendidikan resolusi konflik interpersonal adalah pendidikan perdamaian yang relevan bagi siswa Sekolah Dasar. Pendidikan ini menjawab disrupsi yang terjadi di Indonesia, dan mempengaruhi pola pendidikan penyelesaiaan konflik bagi siswa Sekolah Dasar. Tujuan penelitian ini adalah untuk melihat pemahaman resolusi konflik interpersonal pada siswa, dan mengevaluasi bentuk pendidikan perdamaian yang diterapkan di SDIT Sabilul Huda. Penelitian dilakukan dengan pendekatan penelitian kualitatif. Penelitian kualitatif dalam mengukur keterampilan resolusi konflik interpersonal siswa dalam menguatkan moral kognitif siswa, adalah penggambaran dunia sosial siswa sehari-hari di sekolah. Objek penelitian adalah guru di SDIT Sabilul Huda Kota Cirebon. Hasil penelitian menunjukkan bahwa berdasarkan delapan indikator pertanyaan. Yaitu pemahaman guru tentang Pendidikan resolusi konflik/pendidikan perdamaian bagi anak SD, tujuan pemberian pendidikan resolusi konflik/pendidikan perdamaian bagi anak SD, bentuk pembiasaan pembelajaran pendidikan resolusi konflik/pendidikan perdamaian bagi anak $\mathrm{SD}$, alasan penerapan pendidikan resolusi konflik/pendidikan perdamaian bagi anak SD di dalam, bentuk dukungan sekolah yang diberikan dalam pendidikan resolusi konflik/pendidikan perdamaian bagi anak SD kelas, bentuk kesadaran dan kemampuan siswa SD dalam menyelesaikan konflik interpersonal, bentuk perubahan pengetahuan dan sikap yang ditunjukan oleh siswa SD, dan program sekolah kedepan yang akan diterapkan untuk meningkatkan pendidikan resolusi konflik/pendidikan perdamaian bagi anak SD. Delapan indikator ini dikembangkan dalam instrumen wawancara kepada guru. Dapat ditarik kesimpulan bahwa dalam pendidikan resolusi konflik interpersonal di SDIT Sabilul Huda, pemahaman guru tentang pengertian, tujuan, alasan, dan bentuk pembiasaan pembelajaran resolusi konflik/pendidikan perdamaian sudah
\end{abstract}


sangat baik. Hal ini dikarenakan dukungan sekolah yang senantiasa memberikan penyuluhan bagi guru.

Kata Kunci: moral kognitif; sekolah dasar; resolusi konflik interpersonal

\begin{tabular}{llll}
\hline Received & $: 2021-05-31$ & Approved & $: 2021-07-31$ \\
Reviesed & $: 2021-07-30$ & Published & $: 2021-07-31$
\end{tabular}

cc) () (ㄱornal Cakrawala Pendas is licensed under a Creative Commons Attribution-

ShareAlike 4.0 International License.

\section{Pendahuluan}

Kehidupan yang damai dalam lingkungan interpersonal siswa adalah hal yang diharapkan oleh setiap guru, terlebih orang tua. Pendidikan yang mengajarkan perdamaian atau resolusi konflik adalah tujuan dari pendidikan moral yang diajarkan pada setiap jenjang pendidikan, tidak terkecuali di Sekolah Dasar. Pada lingkungan sekolah, idealnya siswa dapat memahami konsep menghargai perbedaan, hidup rukun, kerjasama, saling menolong, dan memahami konsep berbagi. Namun seringkali konflik terjadi dalam kehidupan sosial siswa di sekolah, karena setiap hari siswa berinteraksi dengan teman-teman di sekolah dan dan itu berkaitan dengan kemampuan resolusi konflik interpersonal siswa.

Pendidikan resolusi konflik atau pendidikan perdamaian bagi siswa Sekolah Dasar harus diajarkan secara masiv. Mengingat sekolah sebagai lembaga pendidikan formal yang menjadi tempat interaksi sosial, sekolah harus menjadi tempat belajar yang menghadirkan iklim yang kondusif. Iklim yang kondusif akan menciptakan lingkunagn yang suportif bagi siswa, dan berdampak pada proses belajar yang mendorong siswa berprestasi. Maftuh (2008) menjelaskan, konflik pada siswa Sekolah Dasar akan semakin berbahaya karena dapat menyebabkan tindakan kriminal. Hal tersebut benar adanya, dalam beberapa berita online bahkan terdapat berita yang menayangkan kejadian tawuran antar pelajar Sekolah Dasar yang berawal dari perbedaan pendapat, dan lain-lain.

Dalam konflik terjadi pengaruh atas dua hal yaitu kerjasama dan persaingan. Maka beberapa cara menghindari konflik dapat dilakukan dengan memperhatikan: komunikasi yang efektif; sifat ramah, suka menolong, dan mendiskusikan segala hal yang menjadi pemantik konflik; membangun komunikasi kelompok yang baik; menghargai pendapat orang lain tanpa mengganggap pendapat diri sendiri adalah yang terbaik; mengakui dan menghormati orang lain dengan bersikap responsif terhadap kebutuhan orang lain; dan kesediaan untuk membantu orang lain (Deutsch, Coleman, \& Marcus, 2016). Pendapat ini sangat reliabel dilakukan dalam kehidupan sosial sehari-hari dan dapat diaplikasikan kepada siswa Sekolah Dasar.

Konflik adalah sebuah gejala sosial yang bisa terjadi pada siapa saja dan dimana saja (Nadya, Malihah, \& Wilodati., 2020). Artinya seluruh individu yang hidup di dunia ini dan melakukan interaksi akan mengalami konflik, bahkan siswa di usia Sekolah Dasar. Konflik yang terjadi pada siswa Sekolah Dasar dapat dialami baik dalam lingkup terkecil seperti dalam keluarga, maupun lingkungan yang lebih besar seperti sekolah atau lingkungan bermain seharihari yang lebih luas karena melibatkan lingkungan sosial yang lebih besar. Kewajiban guru dan sekolah salah satunya adalah menciptakan pemahaman resolusi konflik interpersonal bagi siswa, agar siswa terlatih menyelesaikan konflik sebagai wujud dari pendidikan perdamaian.

Konflik yang terjadi di lingkungan sekolah termasuk konflik interpersonal atau konflik antar pribadi. Setiadi \& Kolip (2011) menjelaskan, konflik terjadi karena adanya perbedaan antar individu dan masing-masing dari mereka saling bersikukuh mempertahankan pendapatnya. Maka terjadinya konflik interpersonal. Siswa Sekolah Dasar akan memiliki 
kemampuan resolusi konflik interpersonal jika Ia dibiasakan untuk mengahadapi konflik, dan dilatih untuk menyelesaikannya oleh guru. Susan (2014) menjelaskan bahwa konflik dalam kehidupan setiap orang akan selalu ada, karena keterlibatan setiap individu memungkinkan munculnya berbagai perbedaan dan menimbulkan perselisihan dan persaingan. Dalam usia psikologisnya, siswa Sekolah Dasar cenderung memiliki egosentris yang tinggi sehingga tidaklah aneh jika mereka sering terlibat konflik dengan teman-teman.

Konflik yang sering terjadi pada siswa Sekolah Dasar berupa konflik yang berujung pada ejekan dan konflik yang berujung pada perkelahian (Ernawati \& Yuliati, 2019) Dua klasifikasi konflik yang terjadi pada siswa Sekolah Dasar ini merupakan contoh konflik interpersonal dan menempatkan pendidikan sebagai kunci pencegahan konflik tersebut. Pendidikan secara komprehensif dapat merubah perilaku individu menjadi lebih positif dan dapat mengembangkan moral kognitif yang positif dalam diri siswa.

Moral kognitif sendiri menurut Kohlberg sebagai tokoh pendidikan moral dalam Safrilsyah, Yusoff \& Othman (2017) dikatakan sebagai kemampuan individu menilai yang benar dan yang salah dengan menafsikan situasi dan menggabungkan keadaan psikologi moral sebelum membuat pertimbangan moral. Moral kognitif adalah kajian yang dilakukan setiap individu yang bertumpu pada bagaimana seseorang membuat pertimbangan moral. Secara sederhana dapat dikatakan bahwa moral kognitif adalah pendidikan moral yang mengharapkan siswa sampai pada pertimbangan-pertimbangan moral, sebelum Ia mengambil keputusan.

istem moral kognitif manusia dalam studi ilmiah, berkaitan dengan cara berfikir yang berkaitan dengan tiga hal: 1) Bagaimana individu memperhatikan dan memperoleh informasi; 2) Bagaimana individu dapat menyimpan informasi dan memprosesnya di dalam otak; dan 3) Bagaimana individu memecahkan masalah, berfikir dan merumuskan Bahasa (Solso, Maclin, \& Kimberly, 2008).Pendapat ini sesuai dengan pendapat Kohlberg mengenai moral kognitif pada diri individu.

Dalam pemahaman pendidikan perdamaian atau pendidikan resolusi konflik, kemampuan siswa dalam moral kognitif harus dilatihkan agar menciptakan lingkungan yang kondusif. Lingkungan kondusif ini mendorong terciptanya lingkungan sekolah yang sehat bagi siswa menikmati proses belajar yang optimal dan pergaulan sosial yang damai. Kontrol atas keputusan tersebut salah satu kuncinya adalah kemampuan melakukan moral kognitif dalam diri siswa. Melatih kemampuan ini tidak bisa dilakukan sendiri oleh siswa, maka mereka membutuhkan peran pihak luar seperti guru, lingkungan sekolah, dan lingkungan keluarga.

Saat ini dikenal istilah moral kognitif dan kognisi moral. Apakah pengertian kognisi dan kognitif itu sama? Pada dasarnya keduanya memiliki pengertian yang sama menurut Neisser dalam Zelinsky-Wibbelt (2011) Kognitif berarti proses berfikir atau proses menangkap informasi, menyimpan/mengelola, sampai dengan menggunakan kembali informasi tersebut. Sedangkan kognisi dapat diartikan sebagai pemahaman terhadap pengetahuan atau kemampuan untuk memperoleh pengetahuan. Sudjatnika (2016) memandang bahwa kognisi adalah tingkah laku manusia sebagai reaksi yang timbul dari interaksi antara lingkungan dan skema kognitif manusia itu sendiri, kemudian dikembangkan dengan prinsip dasar belajar dalam skema sosial dan moral. Sehingga dapat dikatakan bahwa moral kognitif berangkat dari kognisi sosial yang menghendaki adanya pola tingkah laku manusia dalam skema kognitif berupa nilai moralitas.

Perkembangan moral kognitif siswa SD bisa ditingkatkan dengan penggunaan modelmodel pembelajaran yang mengedepankan pendidikan moral. Hal ini penting karena model pembelajaran moral yang menekankan aspek kognitif, merupakan upaya kongkrit agar siswa 
dapat melampaui tahap perkembangan moral kognitif yang telah dicapai (Satianingsih, Maftuh, \& Syaodih, 2017). Selanjutnya dapat digunakan oleh siswa untuk mencapai tahap yang lebih tinggi. Seperti kurikulum yang diterapkan di Sekolah Dasar Islam Terpadu Sabilul Huda, Cirebon yang meberikan pemahaman pendidikan resolusi konflik interpersonal bagi siswa.

Tujuan penelitian ini adalah untuk: 1) melihat pemahaman resolusi konflik interpersonal pada siswa sekolah dasar; dan 2) Mendapatkan evaluasi dalam pendidikan perdamaian yang diterapkan di sekolah dari guru sebagai penguatan konsep moral kognitif siswa. Penentuan tujuan dalam penelitian penting dilakukan sebagai koridor penelitian. Selain itu Jamal (2011) menjelaskan, penentuan tujuan digunakan untuk menemukan solusi atau jawaban terhadap masalah penelitian yang kita dilakukan.

Selanjutnya dalam kajian penelitian, di dalamnya harus merujuk pada penelitian yang relevan. Penelitian yang relevan sangat dibutuhkan dalam penulisan sebuah karya tulis ilmiah. Fungsinya adalah sebagai bahan kajian untuk membandingkan kebaruan/novelty penelitian dari penelitian-penelitian yang telah ada.

Penelitian Nadya, et al (2020) dengan judul "Kemampuan Resolusi Konflik Interpersonal dan Urgensinya pada Siswa". Dalam penelitian ini dijelaskan bahwa konflik seringkali ditanggapi secara negatif oleh pelaku interaksi, sehingga penyelesaiannya bersifat destruktif. Dikatakan pula, bahwa konflik dapat diselesaikan secara konstruktif melalui pendidikan resolusi konflik. Penelitian dilakukan dengan pendekatan kuantitatif dengan metode survei eskplanatori. Subjek penelitian terdiri dari 90 orang siswa SMA Negeri 2 Cimahi dengan teknik probability sampling. Data diperoleh dan dikumpulkan melaui angket langsung dan berupa angket tertutup. Hasil penelitian menunjukkan: (1) Mayoritas siswa memiliki kemampuan resolusi konflik yang baik ditandai dengan nilai skor kemampuan resolusi konflik yang tinggi dan penyelesaian konflik interpersonal dilakukan secara mandiri; (2) Kemampuan resolusi konflik yang paling dominan adalah kemampuan komunikasi; (3) Kemampuan resolusi konflik yang masih rendah adalah kemampuan mengelola emosi. Kemampuan resolusi konflik dapat dipadukan dengan penerapan nilai luhur budaya Indonesia agar generasi selanjutnya mampu menjadi agen perdamaian sekaligus melestarikan kebudayaan Indonesia. Penelitian ini memiliki implikasi pada siswa, guru, dan sekolah untuk meningkatkan kemampuan resolusi konflik interpersonal pada siswa.

Penelitian Satianingsih et al (2017) dengan judul "Moral Cognitive Development of Primary School Students in Thematic Integrated Curriculum". Dalam penelitian ini dikatakan bahwa perkembangan moral kognitif siswa Sekolah Dasar sangat berkembang melalui kurikulum tematik terintegrasi. Penelitian ini menjelaskan bahwa perkembangan moral kognitif ditandai dengan perubahan nalar, perasaan, dan perilaku tentang standar benar dan salah.

Penelitian Ramadhani (2016) dengan judul "Kemampuan Resolusi Konflik Interpersonal pada Diri Remaja Setelah Mengikuti Conflict Resolution Outbond Training". Dalam penelitian ini dijelaskan bahwa perkembangan anak rentan terhadap konflik. Kondisi ini membutuhkan peran keterampilan moral kognitif dalam menyelesaikan konflik. Tujuan penelitian ini adalah mendeskripsikan bagaimana kualitas keterampilan resolusi konflik remaja setelah mengikuti conflict resolution outbound. Pendekatan dilakukan dengan cara kualitatif, dengan subjek penelitian peserta basecamp. Hasil yang didapatkan menunjukan sikap konstruktif dalam bertransaksi dengan konflik interpersonal yang siswa rasakan dalam kegiatan outbound. Dapat dikatakan bahwa pelatihan semacam ini dapat meningkatkan keterampilan resolusi konflik interpersonal untuk remaja. 


\section{Metode Penelitian}

Penelitian dilakukan dengan pendekatan penelitian kualitatif. Penelitian kualitatif menggambarkan dunia sosial dari sudut pandang atau sudut pandang objek penelitian sebagai informan dalam latar ilmiah penelitian. Menurut Sudaryono (2018) memahami merupakan esensi dari penelitian kualitatif. Memahami sendiri mudah diucapkan, tetapi dalam praktek penelitian membutuhkan kejelian.

Penelitian kualitatif biasanya dilakukan berdasarkan fenomena yang terjadi (Indrawan \& Yaniawati, 2017). Fenomena yang dimaksud dapat berasal dari dunia nyata maupun kesenjangan teori dan research gap. Fenomena tersebut selanjutnya dapat dijadikan sebagai pijakan untuk merumuskan masalah penelitian dan membuat pertanyaan penelitian. Dalam penelitian ini fenomena yang diamati adalah konflik sosial yang terjadi pada siswa Sekolah Dasar yang semakin banyak, sehingga perlu pendidikan pemahaman resolusi konflik interpersonal yang ditanamkan dalam diri siswa agar mereka mereka memiliki keterampilan moral kognitif sebagai kontrol.

Penelitian dilakukan di di SDIT Sabilul Huda Kota Cirebon, dengan objek penelitian yaitu guru-guru disana. Teknik sampling yang digunakan adalah purposive sampling. Dalam Ramadhani (2016) teknik ini dilakukan berdasarkan kriteria tertentu sesuai kebutuhan penelitian. Kriteria tersebut adalah: objek adalah guru yang mempraktekan pendidikan pemahaman resolusi konflik pada siswa, dan guru adalah pengajar pada sekolah yang melakukan pendekatan pendidikan perdamaian. Pengumpulan data melalui teknik wawancara, yang disebar melalui aplikasi google form mengingat kondisi pandemi Covid-19 yang masih membatasi kegiatan tatap muka.

\section{Hasil dan Pembahasan}

Hasil penelitian yang telah dilakukan melalui wawancara kepada Guru Sekolah Dasar Islam Terpadu (SDIT) Sabilul Huda Kota Cirebon, menunjukkan bahwa pendidikan resolusi konflik atau pendidikan perdamaian di sekolah diterapkan sebagai bagian dari kurikulum sekolah yang diaplikasikan dalam pembelajaran sehari-hari. Secara ringkas, bentuk pertanyaan yang digunakan untuk penggalian informasi berisi indikator yang dapat dilihat pada Tabel 1.

Tabel 1. Indikator pertanyaan penelitian

\begin{tabular}{cll}
\hline No & \multicolumn{1}{c}{ Indikator } & \multicolumn{1}{c}{ Tujuan } \\
\hline 1 & $\begin{array}{l}\text { Pemahaman guru tentang Pendidikan } \\
\text { resolusi konflik/pendidikan } \\
\text { perdamaian bagi anak SD }\end{array}$ & $\begin{array}{l}\text { Menggali informasi mengenai pemahaman } \\
\text { guru tentang pendidikan resolusi } \\
\text { konflik/pendidikan perdamaian bagi siswa } \\
\text { SDIT Sabilul Huda. }\end{array}$ \\
2 & $\begin{array}{l}\text { Tujuan pemberian pendidikan resolusi } \\
\text { konflik/pendidikan perdamaian bagi } \\
\text { anak SD }\end{array}$ & $\begin{array}{l}\text { Menggali informasi mengenai tujuan } \\
\text { pendidikan resolusi konflik/pendidikan } \\
\text { perdamaian bagi siswa SDIT Sabilul Huda. }\end{array}$ \\
& $\begin{array}{l}\text { Bentuk pembiasaan pembelajaran } \\
\text { pendidikan resolusi } \\
\text { konflik/pendidikan perdamaian bagi } \\
\text { anak SD }\end{array}$ & $\begin{array}{l}\text { Menggali informasi mengenai pembiasaan } \\
\text { pembelajaran pendidikan resolusi } \\
\text { konflik/pendidikan perdamaian bagi siswa } \\
\text { SDIT Sabilul Huda. }\end{array}$ \\
& $\begin{array}{l}\text { Alasan penerapan pendidikan resolusi } \\
\text { konflik/pendidikan perdamaian bagi } \\
\text { anak SD di dalam kelas }\end{array}$ & $\begin{array}{l}\text { Menggali informasi mengenai alasan } \\
\text { penerapan pendidikan resolusi }\end{array}$ \\
\hline
\end{tabular}


konflik/pendidikan perdamaian bagi siswa SDIT Sabilul Huda.

5 Bentuk dukungan sekolah yang diberikan dalam pendidikan resolusi konflik/pendidikan perdamaian bagi anak SD

6 Bentuk kesadaran dan kemampuan siswa SD dalam menyelesaikan konflik interpersonal

7 Bentuk perubahan pengetahuan dan sikap yang ditunjukan oleh siswa SD

8 Program sekolah kedepan yang akan diterapkan untuk meningkatkan pendidikan resolusi konflik/pendidikan perdamaian bagi anak SD
Menggali informasi bentuk dukungan sekolah dalam pendidikan resolusi

konflik/pendidikan perdamaian bagi siswa SDIT Sabilul Huda.

Menggali informasi mengenai bentuk kesadaran dan kemampuan siswa SDIT Sabilul Huda dalam menyelesaikan konflik interpersonal.

Menggali informasi mengenai bentuk perubahan sikap resolusi konflik interpersonal yang ditunjukkan oleh siswa SDIT Sabilul Huda sebagai penguatan moral kognitif siswa SDIT Sabilul Huda.

Menggali informasi program yang digagas sekolah ke depan untuk meningkatkan pendidikan resolusi konflik/pendidikan perdamaian sebagai penguat moral kognitif bagis siswa

Berdasarkan delapan indikator yang digunakan dalam penggalian informasi, masingmasing indikator memiliki tujuan yang berbeda-beda. Data hasil penelitian yang didapat dari objek penelitian merupakan deskripsi guru mengenai kemampuan siswa SDIT Sabilul Huda dalam melakukan resolusi konflik (sesuai konteks pendidikan perdamaian) sebagai penguatan moral kognitif bagi siswa. Tujuan penyusunan pertanyaan yang digali dalam wawancara adalah kebutuhan penelitian yang ingin dipenuhi. Indikator dikembangkan berdasarkan tujuan penelitian. Mujiono (2002) menegaskan, isi instrumen memegang peranan penting dalam menentukan mutu sebuah penelitian. Validitas data penelitian yang diperoleh ditentukan oleh kualitas instrumen yang digunakan, disamping prosedur pengumpulan data yang ditempuh.

Penyusunan instrumen penelitian sangat penting dalam menunjang keberhasilan penelitian yang sesuai dengan ketercapaian tujuan (Putra, 2017). Tahapan penyusunan instrumen pada penelitian ini adalah: penentuan tujuan penelitian, penentuan indikator pertanyaan sesuai tujuan, validasi instrumen, perbaikan instrumen, pengambilan data (wawancara), penafsiran data.

Hasil wawancara pada guru di SDIT Sabilul Huda diperoleh fakta yang ditampilkan dalam Tabel 2. Fakta menurut Sibua \& Iskandar F (2016) adalah keadaan atau peristiwa nyata yang tak terbantahkan kebenarannya. Fakta penelitian adalah keadaan atau peristiwa yang ditemui dalam proses penelitian, dapat berupa kejadian, simbol, dan sebagainya. Memiliki peran terhadap teori yang ingin dibuktikan, dalam penelitian kualitatif fakta penelitian menjadi jawaban terhadap tujuan yang ingin digali.

Tabel 2. Fakta Penelitian Kemampuan Resolusi Konflik Interpersonal siswa SD

\begin{tabular}{cll}
\hline No & \multicolumn{1}{c}{ Tujuan } & \multicolumn{1}{c}{ Fakta Penelitian } \\
\hline 1 & $\begin{array}{l}\text { Menggali informasi mengenai } \\
\text { pemahaman guru tentang } \\
\text { pendidikan resolusi } \\
\text { konflik/pendidikan perdamaian } \\
\text { bagi siswa SDIT Sabilul Huda }\end{array}$ & $\begin{array}{l}\text { Guru-guru di SDIT Sabilul Huda memiliki } \\
\text { pemahaman konsep yang baik mengenai pendidikan } \\
\text { resolusi konflik/pendidikan perdamaian bagi siswa }\end{array}$ \\
\hline
\end{tabular}




\begin{tabular}{cl}
\hline No & \multicolumn{1}{c}{ Tujuan } \\
\hline 2 & $\begin{array}{l}\text { Menggali informasi mengenai } \\
\text { tujuan pendidikan resolusi } \\
\text { konflik/pendidikan perdamaian } \\
\text { bagi siswa SDIT Sabilul Huda }\end{array}$ \\
& \\
$3 \quad$ & $\begin{array}{l}\text { Menggali informasi mengenai } \\
\text { pembiasaan pembelajaran } \\
\text { pendidikan resolusi } \\
\text { konflik/pendidikan perdamaian } \\
\text { bagi siswa SDIT Sabilul Huda }\end{array}$
\end{tabular}

4 Menggali informasi mengenai alasan penerapan pendidikan resolusi konflik/pendidikan perdamaian bagi siswa SDIT Sabilul Huda

$5 \quad$ Menggali informasi bentuk dukungan sekolah dalam pendidikan resolusi konflik/pendidikan perdamaian bagi siswa SDIT Sabilul Huda

6 Menggali informasi mengenai bentuk kesadaran dan kemampuan siswa SDIT Sabilul Huda dalam menyelesaikan konflik interpersonal

7 Menggali informasi mengenai bentuk perubahan sikap resolusi konflik interpersonal yang ditunjukkan oleh siswa SDIT Sabilul Huda sebagai penguatan moral kognitif siswa SDIT Sabilul Huda

8 Menggali informasi program yang digagas sekolah ke depan untuk meningkatkan pendidikan resolusi konflik/pendidikan perdamaian sebagai penguat moral kognitif bagis siswa
Fakta Penelitian

Tujuan pendidikan resolusi konflik/pendidikan perdamaian yang dimiliki oleh SDIT Sabilul Huda dipahami dengan baik oleh guru-guru. Salah satu tujuannya adalah memberikan pendidikan kepada siswa yang terdampak konflik interpersonal.

Pembiasaan pembelajaran terkait pendidikan resolusi konflik/pendidikan perdamaian di SDIT Sabilul Huda diberikan setiap hari baik dalam konteks pembelajaran di dalam kelas maupun pembelajaran di rumah. Pembiasaan yang pernah dilakukan berupa pemberian rasa aman dan kepercayaan kepada siswa terdampak konflik interpersonal di lingkungan sekolah.

Salah satu penerapan pendidikan resolusi konflik/pendidikan perdamaian bagi siswa SDIT Sabilul Huda adalah memberikan rasa aman dan kepercayaan kepada siswa terdampak konflik interpersonal di lingkungan sekolah.

Bentuk dukungan sekolah dalam pendidikan resolusi konflik/pendidikan perdamaian bagi siswa SDIT Sabilul Huda adalah melalui kegiatan penyuluhan bagi guru, sehingga guru-guru memiliki pemahaman yang sama mengenai urgensi pendidikan perdamaian bagi siswa SD.

Bentuk kesadaran dan kemampuan siswa SDIT Sabilul Huda dalam menyelesaikan konflik interpersonal salah satunya dengan toleransi dan semangat saling membantu. Dapat dikatakan bahwa kesadaran dan kemampuan siswa dalam menyelesaikan masalah menjadi lebih baik.

Perubahan sikap terkait resolusi konflik interpersonal yang ditunjukkan oleh siswa SDIT Sabilul Huda mendukung proses pemerolehan suasana belajar yang baik, dari kemampuan ini siswa menjadi merasa lebih nyaman.

Program yang digagas sekolah adalah program penyuluhan pendidikan resolusi konflik/pendidikan perdamaian secara berkesinambungan.

Pemahaman konsep yang baik mengenai pendidikan resolusi konflik interpersonal bagi guru sangat dibutuhkan untuk melahirkan generasi yang anti konflik. Dewi, S. F. (2019) menjelaskan desain pendidikan resolusi konflik yang harus dipahami guru memuat empat hal, yaitu analisis sumber belajar, penetapan tujuan belajar, isi materi belajar, serta analisis karakter 
isi belajar. Guru di era pendidikan abad-21 harus menguasai teknologi sebagai sahabat belajar baru bagi siswa dalam menemukan informasi. Untuk itu guru dapat melakukan pendidikan resolusi konflik memanfaatkan sumber belajar berupa internet, buku, jurnal, modul, narasumber, video, ensiklopedia, kamus, perpustakaan, bahkan dari lingkungan siswa.

Di SDIT Sabilul Huda, tujuan pendidikan resolusi konflik interpersonal yang dibutuhkan siswa dapat diasumsikan telah dipahami dengan baik oleh guru-guru. Salah satu tujuannya adalah memberikan pendidikan kepada siswa yang terdampak konflik interpersonal. Dewi, S. F. (2019) menjelaskan, tujuan siswa mempelajari pendidikan resolusi konflik adalah untuk memberi pengetahuan mengenai konflik secara positif, memberikan keterampilan problem solving, dan memberikan keterampilan pencegahan dan penyelesaian konflik. Tiga hal ini sangat tepat dijadikan acuan utama tujuan yang dilakukan oleh guru, bahwa siswa sebagai makhluk sosial harus diberikan pemahaman bahwa konflik adalah hal yang wajar terjadi dalam interaksi mereka. Tinggal bagaimana kita melakukan pemecahan konflik tersebut apabila kita terlibat dalam konflik interpersonal.

Dalam hal pembiasaan pembelajaran terkait pendidikan resolusi konflik interpersonal, di SDIT Sabilul Huda guru telah melakukannya secara optimal karena memanfaatkan lingkungan belajar di sekolah maupun di rumah. Pembiasaan pendidikan resolusi konflik berkaitan dengan komitmen sekolah untuk melakukan strategi pembelajaran pengaturan konflik interpersonal yang dialami siswa. Sejatinya siswa yang terlatih untuk melakukan pengaturan konflik, kemampuan problem solving dalam meresolusi konflik dalam diri mereka akan semakin tumbuh seiring waktu. Maka pendidikan moral lebih tepat jika diajarkan melalui praktik bukan sebatas teori, karena akan menjadi penguat moral kognisi bagi siswa.

Banyak cara yang dapat distrategikan oleh guru dalam penerapan pendidikan resolusi konflik interpersonal, bagi guru SDIT Sabilul Huda cara tersebut salah satunya dengan memberikan rasa aman dan kepercayaan kepada siswa yang terdampak konflik interpersonal di lingkungan sekolah. Strategi pengorganisasian pendidikan resolusi konflik interpersonal dengan membuat urutan (sequenzing) dan membuat perpaduan (synthesizing) antara fakta, konsep, prosedur, dan prinsip yang berkaitan dengan teori dan isi pembelajaran. Dewi, S. F. (2019) menjelaskan, dalam pendidikan resolusi konflik yang terdiri dari tiga tujuan. Ketiganya terbagi menjadi pembelajaran mikro (mengacu pada metode pembelajaran yang dapat digunakan cukup melalui pengenalan atau pemahaman satu konsep saja), dan pembelajaran makro (mengacu pada metode pembelajaran yang melibatkan lebih banyak konsep/prosedur/prinsip). Pembagian tersebut dapat dilihat pada Gambar 1.

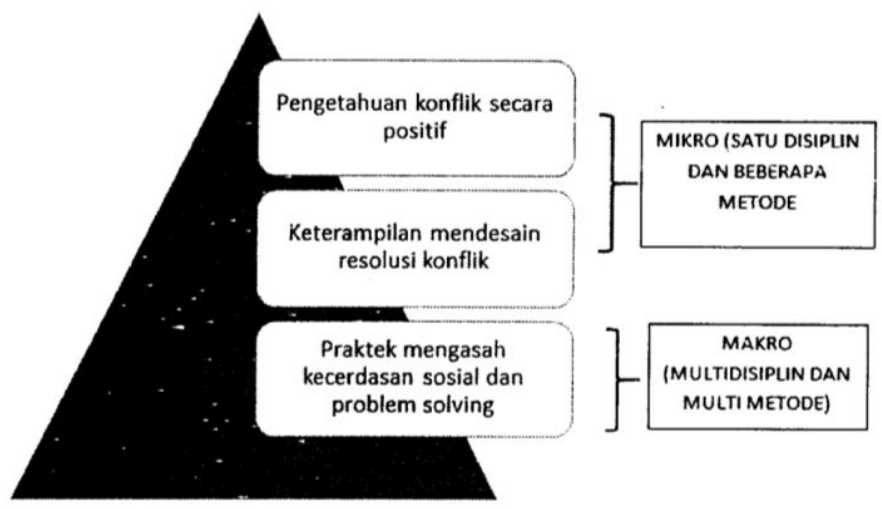

*Sumber: Dewi, S. F.(2019)

Gambar 1. Pembagian pembelajaran mikro dan makro dalam pendidikan resolusi konflik 
Pendidikan resolusi konflik atau pendidikan perdamaian di Sekolah dasar adalah kebutuhan saat ini, mengingat interaksi sosial individu saat ini bukan hanya interaksi fisik semata. Tetapi interaksi yang juga dilakukan lewat media sosial. Interaksi dalam dunia maya juga dapat menimbulkan gesekan sosial yang berdampak pada timbulnya konflik. Untuk itu guru perlu dibekali dengan penyuluhan. SDIT Sabilul Huda memberikan kegiatan penyuluhan tentang berbgai kompetensi kepada guru, salhsatunya tentang urgensi pendidikan resolusi konflik bagi siswa, sehingga guru-guru memiliki pemahaman yang memadai mengenai pendidikan perdamaian yang sesuai bagi siswa SD.

Bentuk kesadaran bagi siswa Sekolah Dasra dalam menolerir konflik dapat dilakukan dengan berbagai cara, salah satu cara yang dilakukan guru di SDIT Sabilul Huda dalam menyelesaikan konflik interpersonal adalah melakukan praktik toleransi dan semangat saling membantu. Melalui kegiatan praktik ini, siswa memiliki semangat toleransi yang lebih tinggi. Dalam praktik ini akan mendorong siswa memiliki pemahaman moral kognitif yang baik, dan dapat Ia aplikasikan menjadi moral aksi.

Pembangunan suasana sekolah yang nyaman, terhindar dari konflik karena mengedepankan toleransi, pemahaman problem solving atas konflik, dan pembiasaanpembiasaan positif. Akan mendukung proses pemerolehan suasana belajar yang baik di lingkungan sekolah, dari pengasahan keterampilan ini siswa akan mendapatkan perasaan nyaman dalam kegiatan belajar di sekolah. Secara tidak langsung, proses pembiasaan ini akan melatih pembentukan moral kognitif siswa.

\section{Kesimpulan}

Pendidikan resolusi konflik interpersonal secara masiv bagi siswa Sekolah Dasar saat ini dapat dikatakan sudah sangat penting, atau dapat dikatakan menjadi urgensi. Konflik yang terjadi pada siswa Sekolah Dasar yang berpotensi pada kekerasan telah menjadi momok buruk, karena dampak yang ditimbulkan akan sangat berpengaruh terhadap cara mereka menyelesaikan konflik. Artinya jika berbicara tentang cara penyelesaian konflik yang cenderung negatif atau mengedepankan cara pemecahan konflik dengan mimilih jalan pintas, mereka telah mengalami kegagalan dalam proses moral kognitif. Dapat ditarik kesimpulan bahwa siswa di SDIT Sabilul Huda memiliki pemahaman resolusi konflik/pendidikan perdamaian yang sudah cukup baik. Menurut guru siswa telah mampu melakukan pengambilan-pengambilan keputusan yang positif ketika mereka menghadapi konflik-konflik sederhana.

\section{Daftar Pustaka}

Deutsch, M., Coleman, P. T., \& Marcus, E. C. (2016). The Handbook of Conflict Resolution, Theory and Practice. United State of America: Joseey-Bass.

Dewi, S. F., et al. (2019). Desain Pendidikan Resolusi Konflik. Purwokerto: CV. IRDH.

Ernawati, \& Yuliati, A. (2019). Strategi Pemecahan Konflik Siswa Sekolah Dasar di Kabupaten Bangkalan. Jurnal Civic Culture: Jurnal Ilmu Pendidikan PKn dan Sosial Budaya, 3(1), 211225.

Indrawan, R., \& Yaniawati, P. (2017). Metodologi Penelitian. Bandung: PT. Refika Aditama. Jamal, S. (2011). Merumuskan tujuan dan manfaat penelitian. Jurnal Ilmiah Dakwah dan Komunikasi Al-Munir, III(5), 147-157.

Maftuh, B. (2008). Pendidikan Resolusi Konflik. Bandung: Program Studi Pendidikan Kewarganegaraan Sekolah Pascasarjana Universitas Pendidikan Indonesia.

Mudjiono, P. (2002). Penyusunan dan Pengembangan Instrumen Penelitian. Disampaikan pada Lokakarya Peningkatan Suasana Akademik, Jurusan Ekonomi FIS_UNJ.

Nadya, F., Malihah, E., \& Wilodati. (2020). Kemampuan Resolusi Konflik Interpersonal dan Urgensinya pada Siswa. Jurnal Sosietas, 10(1), 774-790. 
Putra, H. D. (2017). Pengembangan Instrumen untuk Meningkatkan Kemampuan Mathematical Problem Posing Siswa SMA. Jurnal Euclid, 4(1), 604-688.

Ramadhani, H. S. (2016). Kemampuan Resolusi Konflik Interpersonal pada Diri Remaja Setelah Mengikuti Conflict Resolution Outbound Training. Persona, Jurnal Psikologi Indonesia, 5(3), 187-193.

Safrilsyah, Yusoff, M. Z. B. M., \& Othman, M. K. B. (2017). Moral dan Akhlaq dalam psikologi Moral Islami. Psikoislamedia Jurnal Psikologi, 2(2), 155-169.

Satianingsih, S., Maftuh, B., \& Syaodih, E. (2017). Moral cognitive development of primary school students in thematic integrated curriculum. In Proceding of International Conference on Education (ICE) Advance in Social Science, Education and Humaniora Research (hal. 402-406).

Setiadi, E. M., \& Kolip, U. (2011). Pengantar Sosiologi Pemahaman Fakta dan Gejala Permasalahan Sosial: Teori, Aplikasi, dan Pemecahannya. Jakarta: Kencana Prenada Media Group.

Sibua, S., \& Iskandar. F. (2016). Kemampuan Mengidentifikasi Faktar dan Opini dalam Teks Surat KABAR MELALUI Kegiatan Mebaca Intensif Siswa Kelas VIII SMP Negeri 4 Kota Ternate. Jurnal Edukasi-Jurnal Pendidikan, 14(1), 355-363.

Solso, R. L., Maclin, O. H. M., \& Kimberly, M. (2008). Psikologi Kognitif Edisi 8 (Terjemahan Mikael Rahardanto dan Kristianto Batuadji). Jakarta: Erlangga.

Sudaryono. (2018). Metodologi Penelitian. Depok: Rajawali Press.

Sujatnika, T. (2016). Tinjauan kognisi sosial terhadap sosial budaya. Jurnal al-Tsaqafa, 13(1), $159-176$.

Susan, N. (2014). Pengantar Sosiologi Konflik. Jakarta: Kencana.

Zelinsky-Wibbelt, C. (2011). Discourse and the Continuity of Reference: Representing Mental Categorization. New York: Mounton de Gruyter. 